\title{
Management of complications associated with the use of hyaluronic acid fillers. Recommendations of the Aesthetic Dermatology Section of the Polish Dermatological Society
}

\author{
Postępowanie przy powikłaniach po zabiegach z użyciem kwasu hialuronowego. \\ Rekomendacje Sekcji Dermatologii Estetycznej Polskiego \\ Towarzystwa Dermatologicznego
}

\author{
Barbara Zegarska', Marcin Ambroziak², Małgorzata Ornatowska³, Wioletta Barańska-Rybak ${ }^{4}$ \\ 'Collegium Medicum in Bydgoszcz, Nicolaus Copernicus University in Torun, Poland \\ 2Ambroziak Clinic, Warsaw, Poland \\ ${ }^{3}$ Bona Dea Center of Aesthetic Dermatology, Krakow, Poland \\ ${ }^{4}$ Department of Dermatology, Venereology and Allergology, Medical University of Gdansk, Gdansk, Poland \\ 'Collegium Medicum w Bydgoszczy, Uniwersytet Mikołaja Kopernika w Toruniu, Polska \\ ${ }^{2}$ Klinika Ambroziak, Warszawa, Polska \\ ${ }^{3}$ Bona Dea Centrum Dermatologii Estetycznej, Kraków, Polska \\ ${ }^{4}$ Katedra i Klinika Dermatologii, Wenerologii i Alergologii, Gdański Uniwersytet Medyczny, Gdańsk, Polska \\ Dermatol Rev/Przegl Dermatol 2020, 107, 15-31 \\ DOI: https://doi.org/l0.5। |4/dr.2020.93968
}

\author{
CORRESPONDING AUTHOR/ \\ ADRES DO KORESPONDENCJI: \\ dr n. med. Marcin Ambroziak \\ Klinika Ambroziak \\ al. Sikorskiego 13/U1 \\ 02-758 Warszawa, Polska \\ tel.: +48602764525 \\ e-mail: marcinambroziak@ \\ klinikaambroziak.pl
}

\begin{abstract}
The most common treatments in the field of aesthetic dermatology and broadly understood aesthetic medicine are those with the use of fillers. For many, hyaluronic acid injections are considered very safe and the effects predictable. Therefore, the widely recognised reversibility of the effects of hyaluronic acid fillers and the growing variety of approved applications and formulations of these products increase their popularity. There are also numerous undesirable effects and complications, especially due to the fact that these treatments are performed both by unauthorised persons and under inappropriate conditions. Complications may be related to: incorrect injection technique, lack of treatment asepsis, reaction of the body to the presence of a foreign body and anatomical changes. Depending on the time when complications occur after hyaluronic acid administration, following complications may be distinguished: immediately complications that occur immediately or up to 3-5 days after administration are and late complications that occur even after several weeks, months or even years. Non-vascular complications of hyaluronic acid administration are: nodules, granulomas, persistent swelling, Tyndall effect, infections and biofilm. The most dangerous are vascular complications after hyaluronic acid administration, such as: ischaemia/partial or complete necrosis, vision abnormalities and blindness. Early recognition of a complication largely prevents permanent defects. The use of hyaluronidase injections is considered management of choice in the treatment of complications of hyaluronic acid fillers and should be performed immediately after the procedure with the use of the filler. Therefore, it was necessary to develop a consensus on the principles of hyaluronidase administration for complications of hyaluronic acid filler procedures.
\end{abstract}




\section{STRESZCZENIE}

Do najczęstszych zabiegów z zakresu dermatologii estetycznej i szeroko rozumianej medycyny estetycznej należą zabiegi z zastosowaniem wypełniaczy. Przez wiele osób iniekcje kwasu hialuronowego uznawane są za bardzo bezpieczne, a efekty jego stosowania za przewidywalne. $Z$ jednej strony powszechnie przyjmowana odwracalność wypełniaczy z kwasem hialuronowym oraz wzrastająca różnorodność zatwierdzonych zastosowań i receptur tych produktów zwiększają ich popularność, a z drugiej strony jednocześnie występują liczne objawy niepożądane i powikłania, zwłaszcza że zabiegi te wykonywane są zarówno przez osoby nieuprawnione, jak i w nieodpowiednich warunkach. Komplikacje mogą być związane z: nieprawidłową techniką wstrzykiwania, brakiem aseptyki zabiegu, reakcją organizmu na obecność ciała obcego oraz zmiennościami anatomicznymi. W zależności od czasu powstania powikłań po podaniu kwasu hialuronowego można wyróżnić powikłania wczesne, natychmiast po podaniu lub do 3-5 dni od podania, oraz późne, które pojawiają się po kilku tygodniach, miesiącach, a nawet latach. Powikłaniami po podaniu kwasu hialuronowego o charakterze nienaczyniowym są: guzki, ziarniniaki, przetrwały obrzęk, efekt Tyndalla, infekcje i biofilm. Najbardziej niebezpieczne są powikłania po podaniu kwasu hialuronowego o charakterze naczyniowym, takie jak niedokrwienie lub martwica częściowa lub całkowita oraz zaburzenia widzenia i ślepota. Wczesne rozpoznanie powikłania znacznie zapobiega powstaniu trwałych defektów. Zastosowanie iniekcji z hialuronidazy uważane jest za złoty standard w leczeniu powikłań po wypełniaczach z kwasu hialuronowego i powinno być wykonane natychmiast po zabiegu. Dlatego konieczny jest konsensus dotyczący zasad podawania hialuronidazy w przypadku powikłań po wypełniaczach z kwasu hialuronowego.

Key words: hyaluronic acid, hyaluronidase, complications.

Słowa kluczowe: kwas hialuronowy, hialuronidaza, powikłania.

\section{INTRODUCTION}

The most common treatments in the field of aesthetic dermatology and broadly understood aesthetic medicine include treatments with the use of fillers, which are a popular non-surgical method of face rejuvenation. According to data from the American Society for Aesthetic Plastic Surgery (ASAPS), in 2016, the number of filler treatments in the United States was 2.7 million, more than half of which were performed with the use of hyaluronic acid (HA) preparations. For comparison, about 600,000 such treatments were performed in 2000 $[1,2]$. However, referring to the information of the International Society of Aesthetic Plastic Surgery (ISAPS), almost 3.3 million treatments with HA were performed in 2017 [3].

Similarly, the number of treatments in Poland increases from year to year, however, there are no ac-

\section{WPROWADZENIE}

Do najczęstszych zabiegów z zakresu dermatologii estetycznej i szeroko rozumianej medycyny estetycznej należą zabiegi z zastosowaniem wypełniaczy, które stanowią popularną niechirurgiczną metodę odmładzania twarzy. Według danych American Society for Aesthetic Plastic Surgery (ASAPS) w 2016 roku liczba zabiegów z zastosowaniem wypełniaczy w Stanach Zjednoczonych wyniosła 2,7 miliona, z czego ponad połowa była wykonana preparatami kwasu hialuronowego (hyaluronic acid - HA). Dla porównania - w 2000 roku wykonano ok. 600 tysięcy tego typu zabiegów [1, 2]. Zgodnie z informacjami International Society of Aesthetic Plastic Surgery (ISAPS) w 2017 roku zostało przeprowadzonych prawie 3,3 miliona zabiegów z użyciem HA [3].

W Polsce również obserwuje się z roku na rok zwiększoną liczbę wykonywanych zabiegów, nie ma nato- 


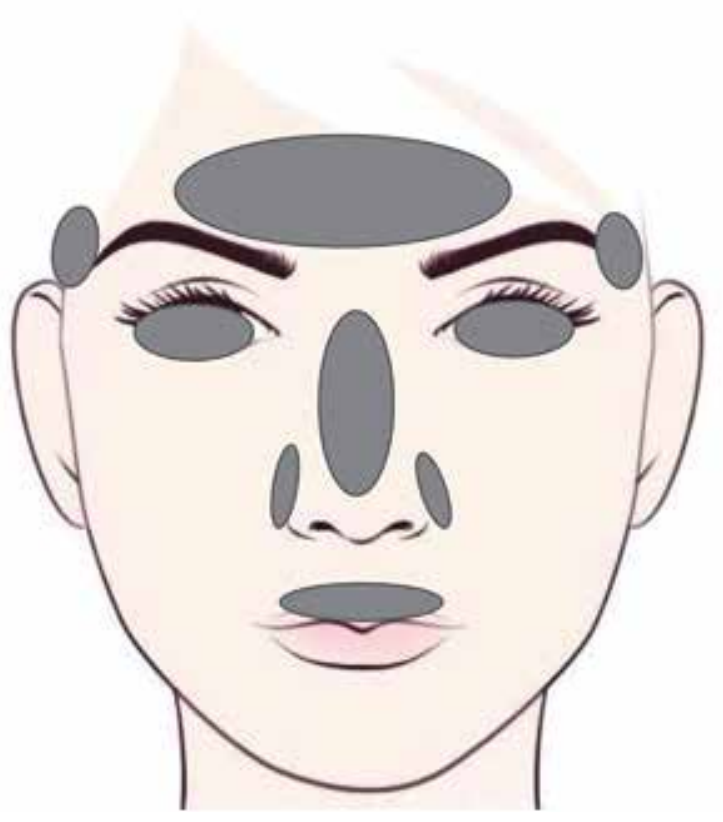

Figure I. Areas of high risk of complications after HA filler administration

Rycina I. Obszary wysokiego ryzyka występowania powikłań po zastosowaniu wypełniaczy HA

curate statistics. The lack of precise data is connected with the carrying out of treatments in various treatment rooms, not only medical ones. For many people, HA injections are considered very safe and the effects are predictable. Therefore, on the one hand, the widely recognised reversibility of the effects of HA fillers and the growing variety of approved applications and formulations of these products increase their popularity, and on the other hand, there are also numerous undesirable effects and complications. About $0.01-1 \%$ of HA administrations result in complications [4]. The hypersensitivity reactions to HA fillers occur in less than $0.15 \%$ of cases [5]. Each HA used has its own unique composition, specific application profile and should be used according to the manufacturer's recommendations. Despite the best techniques and knowledge of anatomy, undesirable symptoms and complication still can be observed, and their number increases with the number of treatments performed. The injection technique should be based on the type of product, quantity and area of injection. A perfect knowledge of the anatomical areas where individual fillers are best suited is crucial for preventing adverse events. The high-risk areas or hazard zones cover especially the following area: forehead, nose, nasolabial folds, mainly the upper $2 / 3$ of the area, temples, upper lip and eyeball area (fig. 1) [6-8].

\section{COMPLICATIONS OF HYALURONIC ACID}

Hyaluronic acid is considered to be the safest preparation used to correct static wrinkles. Hyal- miast dokładnych statystyk. Ten brak dokładnych danych wiąże się z wykonywaniem zabiegów w różnych gabinetach, nie tylko medycznych. Wiele osób uznaje iniekcje HA za bardzo bezpieczne, a efekty jego zastosowania za przewidywalne. $Z$ jednej strony powszechnie przyjmowana odwracalność wypełniaczy z HA oraz wzrastająca różnorodność zatwierdzonych zastosowań i receptur tych produktów zwiększają ich popularność, a z drugiej strony jednocześnie stwierdza się liczne objawy niepożądane i powikłania. Powikłania po podaniu HA występują u ok. 0,01-1\% pacjentów [4]. Reakcje nadwrażliwości na wypełniacze HA obserwuje się w mniej niż 0,15\% przypadków [5]. Każdy HA ma unikalny skład, określony profil zastosowania i powinien być stosowany zgodnie z zaleceniem producenta. Pomimo najlepszych technik i znajomości anatomii nadal występują objawy niepożądane oraz powikłania, a ich liczba wzrasta wraz z liczbą wykonywanych zabiegów. Technika iniekcji powinna być dostosowana do rodzaju produktu, liczby i miejsca iniekcji. Perfekcyjna znajomość anatomicznych obszarów, do których najlepiej nadają się poszczególne wypełniacze, ma kluczowe znaczenie dla zapobiegania zdarzeniom niepożądanym. Obszary wysokiego ryzyka lub strefy zagrożenia obejmują okolicę gładzizny czoła, nosa, fałdów nosowo-wargowych, głównie górne 2/3 tego obszaru, skronie, wargę górną oraz okolicę gałkową (ryc. 1) [6-8].

\section{POWIKŁANIA PO KWASIE HIALURONOWYM}

Kwas hialuronowy uznawany jest za najbezpieczniejszy preparat stosowany w celu korekcji zmarsz- 
uronic acid is a polysaccharide commonly found in mammalian skin and connective tissue. The material of the HA gel matrix acts as a scaffolding for binding structural proteins such as collagen and elastin. From a point of view of safety, HA fillers have several advantages over other fillers: they have better lifting properties (less volume is required to get a lift in the middle of the face), better durability and no requirement to test for skin allergy, and the fact that the effects of HA fillers can be reversed with the use of hyaluronidase. An additional safety-related advantage of HA is the fact that over time they undergo natural degradation by the organism [9].

Undesirable events after its application are rare. The increase in the number of such procedures also results in an increase in the number of complications and adverse effects, especially as these procedures are performed both by unauthorised persons and in inappropriate conditions. Complications may be related to:

- incorrect injection technique,

- lack of asepsis of the procedure,

- the body's reaction to the presence of a foreign body,

- anatomical variations.

The majority of complications can be reduced or completely eliminated by maintaining sterile conditions and using the proper injection technique [10]. Then the question is, how can we safely perform HA injections? Good knowledge of anatomy is essential. It seems simple to make an aspiration test, but such a test can be misleadingly negative. Aspiration with a syringe of $\mathrm{HA}$ with a $12 \mathrm{G}$ needle sometimes takes several seconds for blood to appear. If the syringe is equipped with a $21,23,26$, or $30 \mathrm{G}$ needle, it may produce a definitely misleading result, thus asserting the doctor that it is not in the vessel. Injections with thin cannulas, such as $27 \mathrm{G}$, can be dangerous as the cannula can pierce the vessel as well.

Currently it is recommended to administer HA using 25G or thicker cannulas. Most authors recommend administering the substance in small amounts of $0.1 \mathrm{ml}$ per passage and relatively slowly [11-13].

Early diagnosis of a complication or adverse effect largely prevents permanent defects. Depending on the time of post-HA administration complications, we can distinguish between early complications that occur immediately or up to 3-5 days after administration and late complications that occur even after several weeks, months or years $[9,14]$.

A more accurate breakdown would be to separate two groups of complications:

I. Complications following non-vascular administration of HA:

1) nodules,

2) granulomas, czek statycznych. Kwas hialuronowy jest polisacharydem powszechnie występującym w skórze ssaków i tkance łącznej. Materiał matrycy żelowej HA działa jako rusztowanie do wiązania białek strukturalnych, takich jak kolagen i elastyna. Ze względu na bezpieczeństwo wypełniacze HA mają kilka zalet w porównaniu z innymi wypełniaczami, takich jak lepsza nośność (wymagana jest mniejsza objętość preparatu, aby uzyskać uniesienie w środkowej części twarzy), lepsza żywotność, brak wymogu badania alergii skórnej oraz fakt, że efekty działania wypełniaczy HA można odwrócić za pomocą hialuronidazy. Dodatkową zaletą HA związaną z bezpieczeństwem jest to, że z czasem ulega naturalnej degradacji przez organizm [9].

Zdarzenia niepożądane po zastosowaniu HA są rzadkie. Wzrost liczby tego typu zabiegów skutkuje również zwiększeniem liczby powikłań i objawów niepożądanych, zwłaszcza że zabiegi wykonywane są zarówno przez osoby nieuprawnione, jak i w nieodpowiednich warunkach. Komplikacje mogą być związane z:

- nieprawidłową techniką wstrzykiwania,

- brakiem aseptyki zabiegu,

- reakcją organizmu na obecność ciała obcego,

- zmiennościami anatomicznymi.

Większość powikłań można ograniczyć lub zupełnie wyeliminować przy zachowaniu sterylnych warunków zabiegu oraz przy zastosowaniu prawidłowej techniki iniekcji [10]. Powstaje więc pytanie, jak wykonywać bezpiecznie iniekcje z HA. Podstawą jest dobra znajomość anatomii. Proste wydawałoby się wykonywanie próby aspiracji, jednak taka próba może być mylnie ujemna. Aspiracja strzykawką z HA z igłą 12G wymaga czasami kilkunastu sekund do pojawienia się krwi. Gdy strzykawka zaopatrzona jest w igłę 21, 23, 26 lub 30G, może dawać wynik zdecydowanie mylny, utwierdzając lekarza, że nie jest w naczyniu. Również iniekcje przy użyciu cienkich kaniul, np. 27G, mogą być niebezpieczne, ponieważ kaniula może przebić naczynie.

Obecnie rekomenduje się podawanie HA przy użyciu kaniul 25G lub grubszych. Większość autorów zaleca podawanie substancji w małych ilościach, 0,1 ml na przejście, i stosunkowo powoli [11-13].

Wczesne rozpoznanie powikłania lub objawu niepożądanego istotnie zapobiega powstaniu trwałych defektów. W zależności od czasu powstania po podaniu HA można wyróżnić powikłania wczesne, natychmiast po podaniu lub do 3-5 dni od podania, oraz późne, które pojawiają się po kilku tygodniach, miesiącach, a nawet latach $[9,14]$.

Trafniejszym podziałem jest wyodrębnienie dwóch grup powikłań:

I. Powikłania po podaniu HA o charakterze nienaczyniowym:

1) guzki,

2) ziarniniaki, 
3) chronic oedema,

4) Tyndall effect,

5) infections,

6) biofilm.

II. Complications following vascular administration of HA:

1) ischaemia/necrosis:

a) partial,

b) total,

2) blindness/visual disturbances $[15,16]$.

\section{Nodules}

Nodules are early complications following too shallow (e.g. intradermal) administration of HA or due to inappropriate selection of the filler for a particular patient and surgical area. They usually occur up to 4 weeks after injection, they are firm, limited, remain the same size until they are absorbed, treated or removed. In some cases, a massage, puncture and mechanical extrusion of acid or an injection of 5$150 \mathrm{IU} / 1 \mathrm{ml}$ of hyaluronidase is sufficient to eliminate the nodule. Most authors recommend upper doses of hyaluronidase $[10,14,17,18]$.

\section{Granulomas}

Granulomas appear as a defensive reaction to the foreign body, several weeks, months or even years after the treatment. The cause of lesions is unknown. Sometimes lesions occur during viral or bacterial infection that act as a stimulus, causing the reactivation of macrophages to trigger a sudden reaction to the foreign body. There are also theories stating that this may be a secondary response to the contamination associated with the fermentation process. They may be occur at all points of filler application, are of different sizes, increase in size, and sometimes subside spontaneously. In order to eliminate granulomas we can use combinations of glucocorticosteroid - triamcinolone and 5-fluorouracil in the ratio of $50: 50$. Such treatments are repeated every 4-6 weeks. In case of lack of improvement - excision of lesions is recommended [10, 16, 19].

\section{Chronic oedema}

The chronic oeadma lesions usually occur in the orbital area. The oedema itself may be related not only to the hydrophilic nature of HA, but sometimes it may be a type IV hypersensitivity reaction. Lesions may persist for many weeks, sometimes up to complete biodegradation of the substance. Oedema is reduced after massages, use of arnica creams and antihistamines. In case of chronic oedema, a hyaluronidase dose of 5$50 \mathrm{IU} / 1 \mathrm{ml}$ can be administered $[8,9,20]$.

\section{The Tyndall effect}

The Tyndall effect is characterised by a bluish colour in the orbital area after the administration of
3) przetrwały obrzęk,

4) efekt Tyndalla,

5) infekcje,

6) biofilm.

II. Powikłania po podaniu HA o charakterze naczyniowym:

1) niedokrwienie lub martwica:

a) częściowa,

b) całkowita,

2) ślepota lub zaburzenia widzenia $[15,16]$.

\section{Guzki}

Guzki to powikłania wczesne po zbyt płytko (np. śródskórnie) podanym HA lub spowodowane nieodpowiednim doborem wypełniacza do konkretnego pacjenta i okolicy zabiegowej. Pojawiają się najczęściej do 4 tygodni od podania, są twarde, ograniczone, pozostają tej samej wielkości, dopóki nie zostaną wchłonięte, leczone lub usunięte. W celu likwidacji guzka wystarczy niekiedy masaż, nakłucie i mechaniczne wyciśnięcie kwasu lub podanie niewielkich ilości hialuronidazy 5-150 IU/1 ml preparatu. Większość autorów zaleca podawanie górnych dawek hialuronidazy [10, 14, 17, 18].

\section{Ziarniniaki}

Pojawiają się jako reakcja obronna na ciało obce kilka tygodni, miesięcy lub nawet lat od zabiegu. Przyczyna powstawania zmian nie jest znana. Czasami dochodzi do nich podczas infekcji wirusowej lub bakteryjnej, które działają jako bodziec, co powoduje reaktywację makrofagów w celu wywołania nagłej reakcji na ciało obce. Istnieją też teorie, że może to być wtórna reakcja w stosunku do zanieczyszczeń związanych z procesem fermentacji. Mogą występować we wszystkich punktach podawania wypełniacza, są różnej wielkości, ulegają powiększeniu i niekiedy samoistnie ustępują. W celu likwidacji ziarniniaków można zastosować kombinacje glikokortykosteroidu - triamcynolonu i 5-fluorouracylu w stosunku 50 : 50. Takie zabiegi powtarza się co 4-6 tygodni. W razie braku poprawy zaleca się wycięcie zmian $[10,16,19]$.

\section{Przetrwały obrzęk}

Najczęściej zmiany w postaci przedłużonego obrzęku występują w okolicy oczodołowej. Obrzęk może być związany nie tylko $\mathrm{z}$ hydrofilowym charakterem HA, lecz niekiedy być reakcją nadwrażliwości typu IV. Zmiany mogą się utrzymywać przez wiele tygodni, niekiedy do całkowitej biodegradacji substancji. Obrzęki zmniejszają się po masażach, kremach $\mathrm{z}$ arniką oraz lekach przeciwhistaminowych. W przypadku przedłużającego się obrzęku można zastosować hialuronidazę w dawce 5-50 IU/1 ml $[8,9,20]$.

\section{Efekt Tyndalla}

Efekt Tyndalla charakteryzuje się niebieskawym zabarwieniem w okolicy oczodołowej po podaniu 
hyaluronic acid. It is usually caused by a too superficial administration of acid or by the migration of the substance. It is more common in people with thin skin and fair complexion $[12,21]$.

\section{Infections}

Bacterial infections, mainly streptococcal or staphylococcal infections, can occur as a result of a discontinuity of the skin. They may result from inadequate pre- or post-procedure asepsis as well as the use of contaminated preparation. Changes occur within a few days or within weeks in the case of biofilm. They are typical of inflammatory changes: erythema, swelling, hardening nodules, soreness or tenderness of the area. Treatment is dependent on the severity of the disease process. Topical and/or general application of antibiotics with broad spectrum and high skin penetration (tetracycline, doxycycline, clindamycin) is recommended. In severe cases, it is recommended to incise the lesion to remove the purulent content and to perform inoculation and targeted antibiotic therapy $[10,15,18,22]$.

\section{Biofilm}

The role of biofilm with respect to skin fillers is currently the subject of discussion by many authors. This diagnosis should be taken into account in case of such symptoms as pain, hardening, erythema, swelling occuring after a few weeks at the site of injection. Classic bacterial cultures do not often reveal the presence of bacteria. The most common strains forming the biofilm include: Enterococcus faecalis, Staphylococcus aureus, Staphylococcus epidermidis, Streptococcus viridans, Escherichia coli, Klebsiella pneumoniae, Proteus mirabilis and Pseudomonas aeruginosa. The complex structure of biofim is the cause of their high resistance to various bactericidal agents, including antibiotic resistance [10, 22-24]. The treatment is complicated and long. According to the recommendation of most authors, a thick needle puncture and drainage of the contents should be performed and hyaluronidase should be administered, depending on the extent of the lesion, at a dose of 15-30 IU twice a week for 2-3 weeks. Broad spectrum antibiotics such as ciprofloxacin $500 \mathrm{mg}$ twice daily with clarithromycin $500 \mathrm{mg}$ twice daily or moxifloxacin $400 \mathrm{mg}$ twice daily with clarithromycin $500 \mathrm{mg}$ twice daily for 3-6 weeks are recommended $[25,26]$.

\section{Vascular complications}

The prevalence of vascular disorders remains unknown, however, according to the authors, such a complication may occur even in 3 out of 1000 procedures involving HA. Some recommended injection techniques may minimize the arterial filler injection, but no technique is $100 \%$ effective $[12,14]$. The most common vascular complications occur in the fore-
HA. Spowodowany jest najczęściej zbyt powierzchownym podaniem kwasu lub migracją substancji. Częściej występuje u osób o cienkiej skórze i jasnej karnacji $[12,21]$.

\section{Infekcje}

W wyniku przerwania ciągłości skóry mogą wystąpić infekcje bakteryjne, głównie paciorkowcowe lub gronkowcowe. Mogą być wynikiem zarówno nieodpowiedniej aseptyki przed- lub pozabiegowej, jak i zastosowania zanieczyszczonego preparatu. Zmiany pojawiają się w czasie kilku dni lub tygodni w przypadku biofilmu. Mają charakterystyczną postać zmian zapalnych: rumień, obrzęk, twardniejące guzki, bolesność lub tkliwość okolicy. Leczenie zależy od nasilenia procesu chorobowego. Zaleca się stosowanie miejscowo i/lub ogólnie antybiotyków o szerokim spektrum i wysokiej penetracji do skóry, takich jak tetracyklina, doksycyklina, klindamycyna. W ciężkich przypadkach wskazane jest nacięcie zmiany w celu ewakuacji treści ropnej oraz wykonanie posiewu i wdrożenie celowanej antybiotykoterapii [10, 15, 18, 22].

\section{Biofilm}

Rola biofilmu w przypadku wypełniaczy skórnych jest obecnie tematem dyskusji wielu autorów. To rozpoznanie należy brać pod uwagę w przypadku wystąpienia takich objawów, jak bolesność, stwardnienie, rumień, obrzęk po kilku tygodniach $\mathrm{w}$ miejscu podania wypełniaczy. W klasycznych posiewach bakteryjnych nie stwierdza się często obecności bakterii w hodowli. Do najpowszechniejszych szczepów tworzących biofilm zalicza się: Enterococcus faecalis, Staphylococcus aureus, Staphylococcus epidermidis, Streptococcus viridans, Escherichia coli, Klebsiella pneumoniae, Proteus mirabilis i Pseudomonas aeruginosa. Złożona struktura biofimu jest przyczyną ich wysokiej oporności na działanie różnych czynników bakteriobójczych, w tym na antybiotyki [10, 22-24]. Leczenie jest skomplikowane i długotrwałe. Zgodnie z zaleceniem większości autorów należy wykonać nakłucie grubą igłą i drenaż treści oraz podanie hialuronidazy w zależności od rozległości zmiany w dawce 15-30 IU dwa razy w tygodniu przez 2-3 tygodnie. Zaleca się antybiotyki o szerokim spektrum działania, takie jak cyprofloksacyna w dawce $500 \mathrm{mg}$ dwa razy dziennie z klarytromycyną w dawce $500 \mathrm{mg}$ dwa razy dziennie lub moksyfloksacyna w dawce $400 \mathrm{mg}$ dwa razy dzienne z klarytromycyną $\mathrm{w}$ dawce $500 \mathrm{mg}$ dwa razy dziennie przez 3-6 tygodni $[25,26]$.

\section{Powikłania naczyniowe}

Częstość występowania zaburzeń naczyniowych jest nieznana, ale według autorów powikłanie to może wystąpić nawet w 3 przypadkach na 1000 zabiegów z zastosowaniem HA. Niektóre zalecane techniki iniekcji mogą zminimalizować dotętni- 
head, nasolabial fold, nose and temple area as a result of the administration of a filler to the facial, labial, upper, angular, supratrochlear and supra-orbital arteries, superficial temporal artery and its branches: zygomatico-orbital and frontal (figs. 2 A, B) [4, 15, 27]. Vascular complications may cause skin necrosis, persistent ophthalmoplegia, permanent loss of unilateral or bilateral vision and stroke $[13,17,18]$.

There are three hypotheses regarding pathophysiology associated with ischemia. One of them is vascular compression which refers to high HA pressure on the vessel. Another is the vasoconstriction associated with the tension of muscle layers in the walls of blood vessels in response to a mechanical stimulus. The last cze iniekcje wypełniacza, ale żadna nie jest w 100\% skuteczna $[12,14]$. Najczęściej do powikłań naczyniowych dochodzi w obrębie gładzizny czoła, bruzdy nosowo-wargowej, nosa i okolic skroni w wyniku podania wypełniacza do tętnicy twarzowej, wargowej górnej, kątowej, nadbloczkowej i nadoczodołowej, tętnicy skroniowej powierzchownej i jej gałęzi jarzmowo-oczodołowej oraz czołowej (ryc. 2 A, B) [4, 15, 27]. Powikłania naczyniowe mogą spowodować martwicę skóry, uporczywą oftalmoplegię, trwałą utratę wzroku, jednostronną lub obustronną, oraz udar mózgu $[13,17,18]$.

Istnieją trzy hipotezy dotyczące patofizjologii związanej z niedokrwieniem. Jedną z nich jest kom-
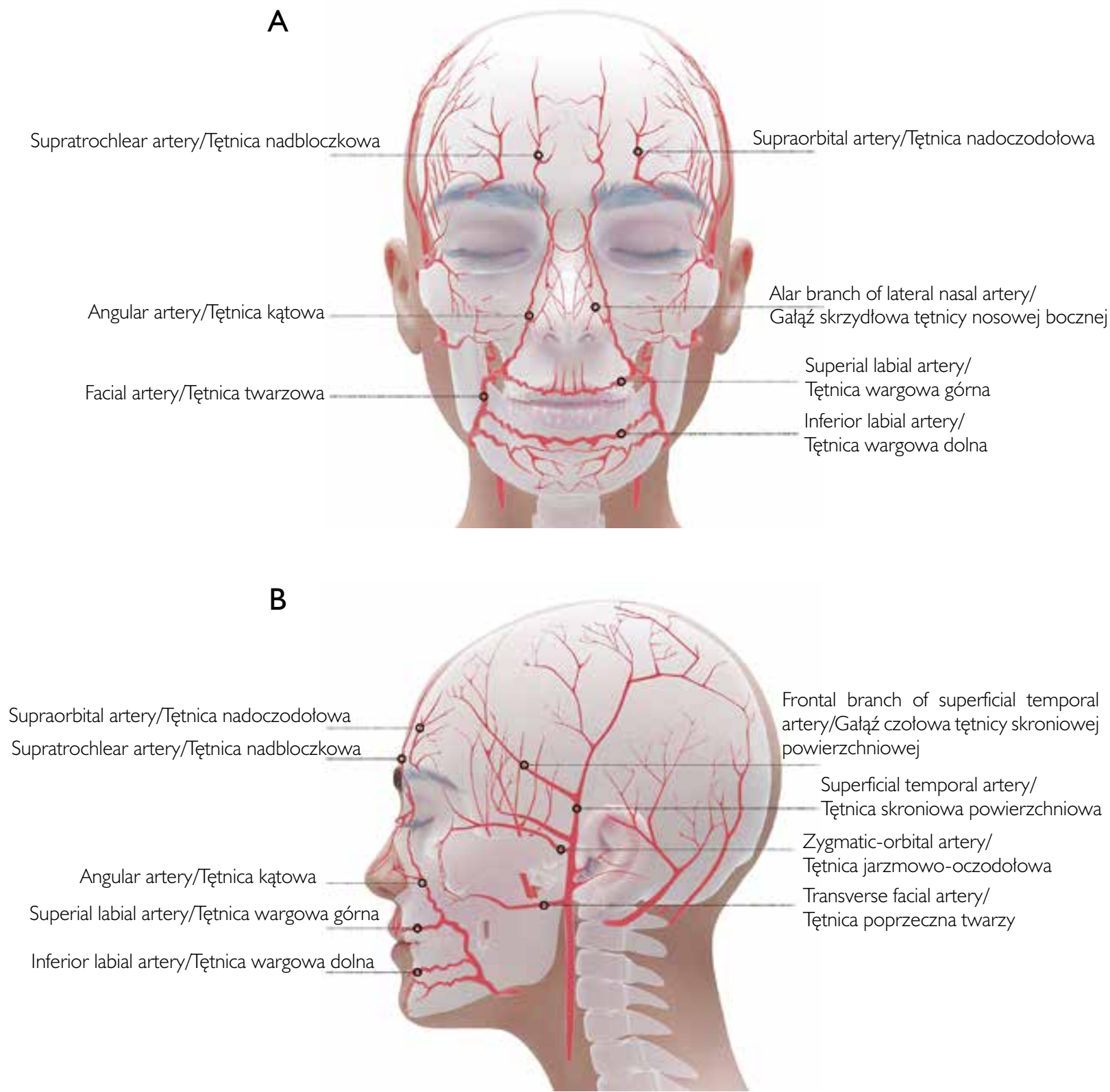

Figure $2 \mathrm{~A}, \mathrm{~B}$. Vascularisation of high risk areas of HA filler complications

Rycina 2 A, B. Unaczynienie obszarów wysokiego ryzyka występowania powikłań po wypełniaczach HA 


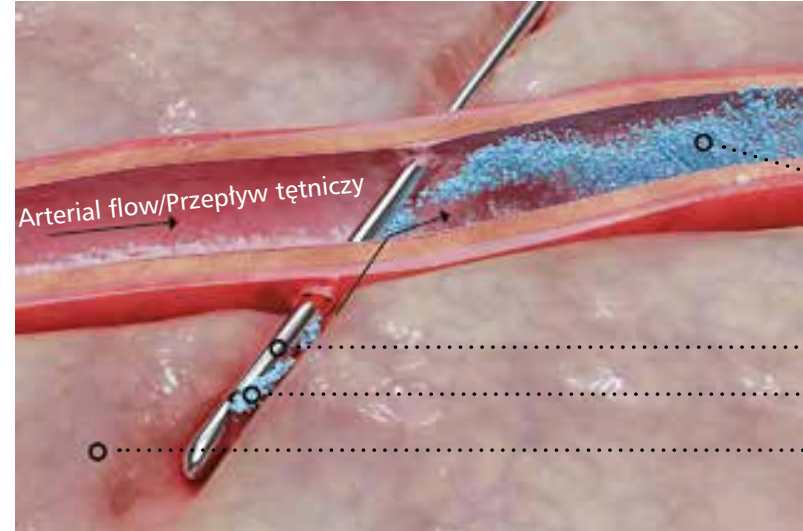

Figure 3. Hyaluronic acid as embolic agent

Rycina 3. Kwas hialuronowy jako materiał zatorowy

one is associated with the occurrence of $\mathrm{HA}$ as a embolic material in the lumen of the vessel at the site of injection and the possibility of its migration to distant places. This happens when the material is injected by arterial means or when the vessel is damaged during injection and HA is injected in a farther area but passes back through a tunnel made with a needle or cannula (fig. 3) [7, 8, 27, 28].

Ischemia caused by external pressure or vasoconstriction is relatively simple and quick to treat. Sometimes they appear even a few hours after the injection and exhibit a typical marble-like appearance and pain. After hyaluronidase administration, the pain or pressure sensation usually disappears quickly, while marbling may remain on the skin for up to 2-3 weeks - gradually decreasing, of course [21, 29, 30]. The HA embolic material in the vascular lumen causes immediate frosting effect [31]. If the physician's reaction is instantaneous and the embolism is small compared to the lumen of the vessel, the reaction can be completely reversible with the vessel regaining its patency. If the physician does not notice or recognise the frosting effect, the patient starts to feel pain and pressure after a few hours. The administration of hyaluronidase is always absolutely recommended even after a few hours or a few days. If there is no immediate reaction and hyaluronidase is not administered, irreversible complications may occur, such as for example tissue necrosis and, in the most severe case, blindness [31-33].

\section{Partial vessel patency impairment}

Occurs when the embolism material does not completely close the vessel light. This can be recognised when we notice a slight pinkishness after a short massage of the frosty area $[15,30,32]$.

\section{Total vessel patency impairment}

This complication manifests itself in typical frosting (confluence), marbling and pain in the injection
Filler in arterial lumen/

Wypełniacz w świetle tętnicy

Injection channel (the filler stays in the places of least resistance)/ Kanał iniekcji (wypełniacz zostaje w miejscach najmniejszego oporu) -FillerMypetniacz

Scar tissue/Tkanka bliznowata

presja naczyniowa, która odnosi się do wysokiego ciśnienia HA uciskającego na naczynie. Kolejna teoria dotyczy skurczu naczyń związanego z naprężeniem warstw mięśniowych w ścianach naczyń krwionośnych w odpowiedzi na bodziec mechaniczny. Ostatnia wiąże się z wystąpieniem HA jako materiału zatorowego w świetle naczynia w miejscu podania i możliwością jego migracji w miejsca odległe. Dzieje się tak, gdy materiał zostanie podany dotętniczo lub gdy w trakcie iniekcji zostanie uszkodzone naczynie, a HA podawany jest $\mathrm{w}$ dalszym obszarze, ale przemieści się wstecznie przez tunel wykonany igłą lub kaniulą (ryc. 3) [7, 8, 27, 28].

Niedokrwienie przez ucisk z zewnątrz lub skurcz naczynia jest stosunkowe proste i szybkie $\mathrm{w}$ terapii. Czasami pojawia się nawet kilka godzin po iniekcji, charakteryzuje się typową marmurkowatością i bólem. Po podaniu hialuronidazy ból lub uczucie ucisku zazwyczaj ustępują szybko, natomiast marmurkowatość może pozostawać na skórze nawet do 2-3 tygodni, oczywiście stopniowo zmniejszając nasilenie [21, 29, 30]. Materiał zatorowy z HA $\mathrm{w}$ świetle naczynia powoduje natychmiastowy efekt wyszronienia [31]. Jeżeli reakcja lekarza jest błyskawiczna i zator jest niewielkich rozmiarów w stosunku do światła naczynia, reakcja może być całkowicie odwracalna z przywróceniem drożności naczynia. Jeśli lekarz nie zauważy bądź nie rozpozna efektu wyszronienia, to po kilku godzinach pacjent zaczyna odczuwać ból i ucisk. Podanie hialuronidazy jest zawsze absolutnie wskazane, nawet po kilku godzinach lub po kilku dniach. W razie braku natychmiastowej reakcji i niepodania hialuronidazy może dojść do nieodwracalnych powikłań, takich jak martwica tkanek, a w najcięższym wypadku ślepota [31-33].

\section{Częściowe upośledzenie drożności naczynia}

Występuje, gdy materiał zatorowy nie zamknie całkowicie światła naczynia. Można to rozpoznać, 
area. It is extremely important for the physician to take appropriate steps, because untreated, it may lead to skin necrosis $[30,32,33]$.

\section{Loss of vision}

Vascular embolism occurs when the injected material shifts from the distal to the proximal artery of the retina, causing sudden, tearing pain, visual impairment, blindness and further tissue necrosis. This is one of the most serious complications that can lead to permanent disability, especially in the absence of appropriate treatment. In the literature review, there are not many reliable reports concerning saving vision after its loss due to HA treatment. The procedure is to prevent further complications, e.g. ischaemic stroke [12, 34-37].

\section{HYALURONIDASE}

It is an enzyme with a molecular weight of $60 \mathrm{kDa}$. It acts at the site of administration, causing hydrolysis of HA by separating the 1.4-glucosamine bond between $\mathrm{C} 1$ of the glucosamine molecule and C4 of the glucuronic acid. Hyaluronidase does not penetrate the blood-brain barrier. There are no large randomised studies on its use in aesthetic medicine and the available knowledge is based on a literature review and practical guidelines from the authors. The use of off-label hyaluronidase in aesthetic medicine was approved by the Food and Drug Administration (FDA) [38, 39]. Hyaluronidase is commercially obtained from sheep or bovine testicles, therefore there is a risk of transmission of a prion disease if the hyaluronidase comes from an unknown source [40].

The first administration of hyaluronidase dates back to 1951, when after adjuvant administration with procaine during local anaesthesia the beneficial effect was obtained [41]. In 1994, Clark and Mellette described the effect after simultaneous administration of hyaluronidase with local anaesthesia during 72 surgeries performed during one year. They demonstrated increased tissue separation during treatments due to reduced tissue oedema [42]. Wohlrab et al. on the other hand, in their study of 44 patients, observed that hyaluronidase combined with lidocaine increases the efficiency and area of local infiltration anaesthesia [43].

After the administration of hyaluronidase, it is immediately dispersed in the tissue and then it quickly returns to its initial state. The time of working of hyaluronidase depends on the area of administration. Immediate effect occurs after contact with the substrate, and its activity time in the skin usually lasts 24 to 48 hours, while in the eye area 60 to 112 hours.

After intravenous administration, hyaluronidase is immediately inactivated and the inactivation mechanism is unknown [44]. gdy po krótkim masażu okolicy wyszronienia stwierdzi się lekkie zaróżowienie [15, 30, 32].

\section{Całkowite upośledzenie drożności naczynia}

Powikłanie to objawia się typowym wyszronieniem (zbieleniem), marmurkowatością i bólem okolicy iniekcji. Bardzo ważne jest sprawne podjęcie odpowiednich kroków przez lekarza, ponieważ nieleczone może prowadzić do martwicy skóry [30, 32, 33].

\section{Utrata widzenia}

Zatorowość oczna powstaje, gdy wstrzyknięty materiał przemieszcza się z dystalnej do bliższej tętnicy siatkówki oka, co powoduje nagły, rozdzierający ból, upośledzenie widzenia, ślepotę i dalszą martwicę tkanek. Jest to jedno z najcięższych powikłań, które może prowadzić do trwałego kalectwa, zwłaszcza w przypadku braku wdrożenia odpowiedniego leczenia. W przeglądzie piśmiennictwa nie ma wielu wiarygodnych doniesień o uratowaniu widzenia po jego utracie spowodowanej zabiegiem z użyciem HA. Postępowanie polega na zapobieganiu dalszym powikłaniom, np. wystąpieniu udaru niedokrwiennego mózgu [12, 34-37].

\section{HIALURONIDAZA}

Jest enzymem o masie cząsteczkowej $60 \mathrm{kDa}$. Działa w miejscu podania, powoduje hydrolizę kwasu hialuronowego poprzez rozdzielenie wiązania 1.4-glukozaminowego pomiędzy C1 cząsteczki glukozaminy i C4 kwasu glukuronowego. Hialuronidaza nie przenika bariery krew-mózg. Brakuje dużych badań z randomizacją dotyczących jej zastosowania w medycynie estetycznej, a dostępna wiedza opiera się na przeglądzie piśmiennictwa i praktycznych wskazówkach autorów. Zastosowanie hialuronidazy off-label w medycynie estetycznej zostało zatwierdzone przez amerykańską Agencję ds. Żywności i Leków (Food and Drug Administration - FDA) [38, 39]. Hialuronidaza jest otrzymywana komercyjnie $z$ jąder owczych lub bydlęcych, dlatego istnieje ryzyko przeniesienia choroby prionowej, gdy pochodzi ona z niewiadomego źródła [40].

Pierwsze podanie hialuronidazy datuje się na 1951 rok, kiedy to uzyskano korzystny efekt po adiuwantowym zastosowaniu z prokainą podczas znieczulenia miejscowego [41]. Clark i Mellette w 1994 roku opisali efekt po jednoczesnym podaniu hialuronidazy z miejscowym znieczuleniem podczas 72 operacji przeprowadzonych w okresie jednego roku. Udowodnili zwiększenie separacji tkankowej podczas zabiegów dzięki zmniejszeniu obrzęku tkankowego [42]. Z kolei Wohlrab i wsp. w badaniu z udziałem 44 chorych zaobserwowali, że hialuronidaza w połączeniu z lidokainą zwiększa efektywność i obszar miejscowego znieczulenia nasiękowego [43]. 

FDA:

Use of hyaluronidase in medicine approved by the

1) addition to saline solution - subcutaneous irrigation in elderly people,

2) increased absorption of drugs administered subcutaneously,

3) elimination of harmful effects of injected drugs (lidocaine, bupivacaine),

4) preventing the harmful effects of extravascular administration of drugs (antibiotics, oncological drugs),

5) urography - improvement of resorption of contrast agents [44].

Off-label indications for hyaluronidase:

1) treatment of hypercorrection after HA administration,

2) treatment of granulomas of foreign body type,

3) treatment of embolism/necrosis after HA administration [44].

The first use of hyaluronidase in aesthetic medicine took place in 2004 in the treatment of overcorrection caused by improper administration of hyaluronic acid. At that time, $75 \mathrm{IU}$ of hyaluronidase (Lee Pharmacy, Inc., Fort Smith, AZ, USA; $50 \mathrm{IU} / \mathrm{ml}$ ) and $1.5 \mathrm{ml}$ of $0.5 \%$ lidocaine with epinephrin were used thus reducing $90 \%$ of irregularities, nodules and overcorrection within 24 hours [45].

There are still no fixed guidelines for the dosage of hyaluronidase in overcorrection/HA shifts, due to the fact that various HA preparations show different susceptibility to degradation after hyaluronidase administration. On the basis of 30 cases described with the use of hyaluronidase, it has been shown that HA substances using VYCROSS technology are $50 \%$ less sensitive to enzymatic degradation by bovine hyaluronidase than other acid preparations. It is believed that in the treatment of facial overcorrection, the efficiency can be achieved using 30-150 IU hyaluronidase per $1 \mathrm{ml} \mathrm{HA} \mathrm{[46].} \mathrm{In} \mathrm{the} \mathrm{eye} \mathrm{area,} \mathrm{the}$ authors recommend small doses of 5-15 IU with possible supplementation of the treatment with the same doses after another 2 weeks [44]. There are different hyaluronidase preparations available on the market demonstrating diversified activity in relation to various HA preparations [47, 48].

Hyaluronidase is also used to treat nodules and granulomas. In such cases, it is recommended to administer 15 to 150 IU hyaluronidase intralesionaly, control after 2 weeks and further hyaluronidase injections depending on the clinical condition. In the risk of necrosis, the authors recommend high doses of hyaluronidase from 500-1,000 IU administering the preparation at the depth of $3-4 \mathrm{~mm}$ in the amount of 0.3-0.5 $\mathrm{ml}$ per injection point [48-50].

Vascular embolism after HA administration is one of the most serious complications and requires large amounts of hyaluronidase - from 1500 IU. It is be-
Po podaniu hialuronidazy następuje jej natychmiastowa dyspersja w tkance, a następnie szybki powrót do stanu wyjściowego. Czas działania hialuronidazy zależy od miejsca podania. Działanie natychmiastowe zachodzi po kontakcie z substratem, a czas aktywności w skórze wynosi średnio 24-48 godzin, natomiast w okolicy oka 60-112 godzin.

Po dożylnym podaniu dochodzi do natychmiastowej dezaktywacji hialuronidazy, a mechanizm dezaktywacji jest nieznany [44].

Zastosowanie hialuronidazy w medycynie zatwierdzone przez FDA:

1) dodatek do soli fizjologicznej - podskórne nawadnianie u osób starszych,

2) wzrost absorpcji leków podawanych podskórnie,

3) zniesienie szkodliwego działania leków podanych $\mathrm{w}$ formie iniekcji (lidokainy, bupiwakainy),

4) zapobieganie szkodliwym skutkom pozanaczyniowego podania leków (antybiotyki, leki onkologiczne),

5) urografia - poprawa resorpcji substancji kontrastujących [44].

Wskazania pozarejestracyjne (off-label) dla hialuronidazy:

1) leczenie hiperkorekcji po podaniu HA,

2) leczenie ziarniniaków typu ciała obcego,

3) leczenie zatoru lub martwicy po podaniu HA [44].

Pierwsze zastosowanie hialuronidazy w medycynie estetycznej miało miejsce w 2004 roku w leczeniu nadkorekcji wywołanej niewłaściwym podaniem HA. Zastosowano wówczas 75 IU hialuronidazy (Lee Pharmacy, Inc., Fort Smith, AZ, USA; $50 \mathrm{IU} / \mathrm{ml}$ ) i 1,5 ml 0,5\% lidokainy z epinefryną, uzyskując redukcję $90 \%$ nierówności, guzków i nadkorekcji w czasie 24 godzin [45].

Nadal nie ma sztywnych wytycznych dotyczących dawkowania hialuronidazy w nadkorekcji lub przemieszczeniu HA, co wynika z faktu, że różne preparaty HA wykazują różną podatność na degradację po podaniu hialuronidazy. Na podstawie opisanych 30 przypadków zastosowania hialuronidazy wykazano, że substancje HA z zastosowaniem technologii VYCROSS są o 50\% mniej wrażliwe na enzymatyczną degradację bydlęcą hialuronidazą niż inne preparaty tego kwasu. Uważa się, że przy leczeniu nadkorekcji w obrębie twarzy efektywność można uzyskać przy zastosowaniu 30-150 IU hialuronidazy na $1 \mathrm{ml} \mathrm{HA}$ [46]. W okolicy oka autorzy zalecają małe dawki 5-15 IU - z ewentualnym uzupełnieniem zabiegu tymi samymi dawkami po kolejnych 2 tygodniach [44]. Na rynku dostępne są preparaty hialuronidazy o zróżnicowanej aktywności w stosunku do różnych preparatów HA $[47,48]$.

Hialuronidaza stosowana jest także w leczeniu guzków oraz ziarniniaków. Zaleca się wówczas doogniskowe podanie 15-150 IU hialuronidazy, kontrolę po 2 tygodniach i dalsze iniekcje tej substancji w zależności od stanu klinicznego. W przypadku zagrożenia martwicą autorzy zalecają duże dawki hia- 
lieved that the best result is obtained after hyaluronidase administration up to 4 hours after HA injection $[51,52]$.

Hyaluronidase may cause both immediate and delayed allergic reactions [46]. The reactions described after hyaluronidase administration concern $<0.1 \%$ of patients treated and include: erythema, pruritus, treated area oedema, urticaria, angioedema.

Experts' opinions on hyaluronidase allergy testing are divided. Kirby et al. recommend intradermal administration of $0.02 \mathrm{ml}$ (3 IU) hyaluronidase and reading the test after 5 minutes. The presence of wheal response, together with accompanying erythema at the site of administration within 5 minutes after injection is interpreted as a positive reaction. According to the authors, the presence of erythema or vascular spot alone should be considered a negative reaction [51].

Allergy testing is justified for the treatment of overcorrection or nodules and granulomas, as well as the Tyndall effect. In the risk of necrosis, hyaluronidase should be administered as soon as possible; there is no time to perform the test.

Relative contraindications for hyaluronidase administration include:

1) patients with hymenoptera venom allergy - risk of cross reactions,

2) patients allergic to bovine collagen,

3) multiple allergy [52].

The following hyaluronidase preparations are available in Poland:

1) DermaQual-Disolvidase - Hialuronidaza (1500 IU) - powder to be dissolved in $9 \mathrm{ml}$ of saline solution;

2) Liquid hyaluronidase - ZIMOJAL ( $5 \mathrm{ml})$ - ready solution $0.05 \mathrm{IU} / \mathrm{ml}$;

3) Hyaluronidase - Liporase (1,500 IU) - powder to be dissolved in $3 \mathrm{ml}$ of saline solution;

4) Desinfiltral - hyaluronidase (1,500 IU) powder to be dissolved in $5 \mathrm{ml}$ of saline solution;

5) Hialuronidase MesoMedica (150 IU/1 ml) - 10 ml.

\section{Recommended treatment schemes in case of complications}

1. Nodules:

a) injection site massage;

b) an attempt to mechanically remove the administered HA by puncturing the injection site and/or squeezing out the material;

c) administration of hyaluronidase preparation in doses of 5-150 IU per $1 \mathrm{ml}$ of previously administered hyaluronic acid; the authors recommend doses in the upper range;

d) control appointment and eventual repeated administration of hyaluronidase the next day $[14,18$, $38,46,48]$. luronidazy - 500-1000 IU, podawane na głębokość 3-4 mm w ilości 0,3-0,5 ml na punkt iniekcji [48-50].

Zatorowość naczyniowa po podaniu HA jest jednym z najpoważniejszych powikłań i wymaga dużych ilości hialuronidazy - od 1500 IU. Uważa się, że najlepszy rezultat osiąga się po podaniu hialuronidazy do 4 godzin od iniekcji HA [51, 52].

Hialuronidaza może być przyczyną zarówno reakcji alergicznej typu natychmiastowego, jak i opóźnionego [46]. Opisywane odczyny po podaniu hialuronidazy dotyczą poniżej $0,1 \%$ leczonych i obejmują rumień, świąd, obrzęk leczonej okolicy, pokrzywkę i obrzęk naczynioruchowy.

Zdania ekspertów odnośnie do wykonywania próby uczuleniowej na hialuronidazę są podzielone. Kirby i wsp. zalecają śródskórne podanie 0,02 ml (3 IU) hialuronidazy i odczyt próby po 5 minutach. Obecność bąbla pokrzywkowego z towarzyszącym rumieniem $\mathrm{w}$ miejscu podania $\mathrm{w}$ czasie 5 minut po iniekcji jest interpretowana jako odczyn dodatni. Obecność tylko rumienia lub plamki naczyniowej według autorów powinna być uznana za odczyn ujemny [51].

Wykonywanie próby uczuleniowej jest uzasadnione w przypadku leczenia nadkorekcji lub guzków i ziarniniaków oraz efektu Tyndalla. W razie zagrażającej martwicy należy jak najszybciej podać hialuronidazę, nie ma czasu na wykonywanie próby.

Przeciwwskazania względne do podania hialuronidazy obejmują:

1) pacjentów uczulonych na jady owadów błonkoskrzydłych - ryzyko wystąpienia reakcji krzyżowych;

2) pacjentów uczulonych na kolagen bydlęcy,

3) alergię wieloważną [52].

W Polsce dostępne są następujące preparaty hialuronidazy:

1) DermaQual-Disolvidase - Hialuronidaza (1500 IU), proszek do rozpuszczenia w $9 \mathrm{ml}$ soli fizjologicznej;

2) hialuronidaza w płynie - ZIMOJAL ( $5 \mathrm{ml})$, gotowy roztwór $0,05 \mathrm{IU} / \mathrm{ml}$;

3) Hialuronidaza - Liporase (1500 IU), proszek do rozpuszczenia w $3 \mathrm{ml}$ soli fizjologicznej;

4) Desinfiltral - Hialuronidaza (1500 IU), proszek do rozpuszczenia w $5 \mathrm{ml}$ soli fizjologicznej;

5) Hialuronidase MesoMedica (150 IU/1 ml) - 10 ml.

\section{Zalecane schematy leczenia powikłań}

1. Guzki:

a) masaż okolicy iniekcji;

b) próba mechanicznego usunięcia podanego HA poprzez nakłucie okolicy iniekcji i/lub wyciśnięcie materiału;

c) podanie preparatu hialuronidazy w dawkach 5-150 IU na $1 \mathrm{ml}$ podanego wcześniej HA; autorzy zalecają podawanie dawek w górnym zakresie;

d) kontrola i ewentualne ponowne podanie hialuronidazy następnego dnia [14, 18, 38, 46, 48]. 
2. Granulomas:

a) administration of triamcinolone at the dose of $40 \mathrm{mg} / \mathrm{ml}$ or 5 -fluorouracil at the dose of $50 \mathrm{mg} /$ $\mathrm{ml}$; both preparations can be administered simultaneously in a $50: 50$ ratio and the treatment can be repeated every 4-6 weeks ( the use of both preparations is off-label);

b) in case of no improvement - excision of lesions [10, 16, 19].

3. Chronic oedema:

a) injection site massage;

b) application of arnica cream and antihistamines in accordance with the Summary of Product Characteristics, e.g. administration of loratidinum in a dose of $10 \mathrm{mg}$ twice a day; administration of drugs until the lesions recede;

c) in case of prolonged oedema - administration of hyaluronidase preparation in doses 5-50 IU/1 ml of previously administered HA $[8,9,20]$;

4. Tyndall effect:

a) injection site massage;

b) an attempt to mechanically remove the administered HA by puncturing the injection site and/or squeezing out the material;

c) administration of hyaluronidase preparation in doses 5-150 IU/1 ml of previously administered $\mathrm{HA}$; the authors recommend doses in the upper range;

d) control appointment and eventual repeated administration of hyaluronidase the next day $[15,21,46]$.

5. Infections and biofilm:

a) an attempt to discharge the contents in the case it is liquid and ordering culture thereof;

b) administration of hyaluronidase at a dose of 150200 IU;

c) if bacterial growth from the culture is demonstrated and biofilm is reasonably suspected, a broadspectrum antibiotic must be administered for at least 3-6 weeks; a long period of antibiotic therapy is suggested; examples of preparations: ciprofloxacin $500 \mathrm{mg}$ twice a day together with clarithromycin $500 \mathrm{mg}$ twice a day or moxifloxacin $400 \mathrm{mg}$ twice a day together with clarithromycin $500 \mathrm{mg}$ twice a day;

d) if there is no improvement, referral to the hospital to administer vancomycin $[15,21,23,24,26]$.

In case of infection, glucocorticosteroid administration should be avoided.

Difficult to treat biofilm may also result from the presence of rheumatic and autoimmune diseases, so it is recommended to perform general and specific tests, depending on the individual case.

6. Partial vessel patency impairment:

a) performing an intradermal test using hyaluronidase; waiting for at least 5 minutes for its results $[50,51]$ with special caution in persons declaring
2. Ziarniniaki:

a) podanie triamcinolonu $\mathrm{w}$ dawce $40 \mathrm{mg} / \mathrm{ml} \mathrm{lub}$ 5-fluorouracylu w dawce $50 \mathrm{mg} / \mathrm{ml}$; można podać oba preparaty jednocześnie w stosunku 50 : 50 i powtarzanie zabiegu co 4-6 tygodni (stosowanie obu tych preparatów jest off-label);

b) w razie braku poprawy - wycięcie zmian [10, 16, 19].

3. Przetrwały obrzęk:

a) masaż okolicy iniekcji;

b) zastosowanie kremu z arniką i leków przeciwhistaminowych zgodnie $\mathrm{z}$ charakterystyką produktu leczniczego, np. podawanie loratydyny w dawce 10 mg dwa razy dziennie; podawanie leków do ustąpienia zmian;

c) w przypadku przedłużającego się obrzęku podanie preparatu hialuronidazy $\mathrm{w}$ dawkach 5-50 IU na $1 \mathrm{ml}$ podanego wcześniej HA $[8,9,20]$.

4. Efekt Tyndalla:

a) masaż okolicy iniekcji;

b) próba mechanicznego usunięcia podanego HA poprzez nakłucie okolicy iniekcji i/lub wyciśnięcie materiału;

c) podanie preparatu hialuronidazy w dawkach 5-150 IU na $1 \mathrm{ml}$ podanego wcześniej HA; autorzy rekomendują podawanie zaleconej dawki w górnym zakresie;

d) kontrola i ewentualne ponowne podanie hialuronidazy następnego dnia $[15,21,46]$.

5. Infekcje i biofilm:

a) próba opróżnienia w przypadku treści płynnej i zlecenie jej posiewu;

b) podanie hialuronidazy w dawce 150-200 IU;

c) w przypadku stwierdzenia wzrostu liczby bakterii z posiewu uzyskanej treści, a także uzasadnionego podejrzenia wystąpienia biofilmu podawanie antybiotyku o szerokim spektrum działania przez co najmniej 3-6 tygodni; sugeruje się długi czas antybiotykoterapii; przykładowe preparaty: cyprofloksacyna 2 razy dziennie po $500 \mathrm{mg}$ z klarytromycyną 2 razy dziennie po $500 \mathrm{mg}$ lub moksyfloksacyna 400 mg dwa razy dzienne z klarytromycyną 500 mg dwa razy dziennie;

d) jeśli nie uzyskano poprawy - skierowanie do szpitala w celu podania wankomycyny [15, 21, 23, 24, 26]. W przypadku infekcji należy unikać podawania glikokortykosteroidów.

Trudno leczący się biofilm może także wynikać z obecności chorób reumatologicznych i autoimmunologicznych, dlatego zaleca się wykonanie badań ogólnych i szczegółowych w zależności od indywidualnego przypadku.

6. Częściowe upośledzenie drożności naczynia:

a) wykonanie testu śródskórnego z użyciem hialuronidazy; należy poczekać co najmniej 5 minut na jego wynik $[50,51]$ i zachować szczególną ostrożność u osób deklarujących reakcję uczuleniową na 
an allergic reaction to hymenoptera venom. It should be remembered to have an anaphylactic emergency kit in the medical room;

b) administration of acetylsalicylic acid at a dose of $600 \mathrm{mg}$;

c) administration of $400 \mathrm{IU}$ of hyaluronidase in several punctures every 3-4 cm into the ischaemic region. It is recommended to administer hyaluronidase using a needle or 25G cannula;

d) use of warming compresses;

e) control after 1 hour; in the case of visible concussion and/or pain, point c should be repeated;

f) control after 6 hours; in the case of visible concussion and/or pain, point c should be repeated;

g) control appointment on the following day; in the case of visible concussion and/or pain, point $c$ should be repeated until concussion and/or pain are completely eliminated $[22,34,38]$.

The use of nitroglycerin is not recommended due to its ability to constrict vessels at longer intervals [53, 54].

7. Total vessel patency impairment:

a) in severe cases, due to possible major complications caused by delayed implementation of the patient's treatment, the intradermal test with hyaluronidase may be waived; great caution should be exercised with people declaring an allergic reaction to hymenoptera venom; it should be remembered to have an anaphylactic emergency kit in the medical room;

b) administration of acetylsalicylic acid at a dose of $600 \mathrm{mg}$;

c) administration of 1000-1500 IU of hyaluronidase or more in several punctures every 3-4 cm into the ischaemic region; it is recommended to administer hyaluronidase using a needle or 25G cannula;

d) use of warming compresses;

e) control after 1 hour; in the case of visible concussion and/or pain, point c should be repeated;

f) control after 6 hours; in the case of visible concussion and/or pain, point $\mathrm{c}$ should be repeated;

g) control appointment on the following day; in the case of visible concussion and/or pain, point $c$ should be repeated until concussion and/or pain are completely eliminated;

h) administration of $400 \mathrm{mg}$ doses of penthoxyphilin twice a day for at least 2 weeks $[29,34,38]$.

8. Loss of vision.

In the case of loss of vision caused by HA treatment, we must remember to hand the patient over to the ophthalmological emergency department as soon as possible. There is a principle of the golden 90 minutes counted from the time of performing the treatment. Call for an ambulance.

The following actions shall be taken when waiting for the ambulance arrival:

a) administration of a single hyaluronidase dose of 1000-1500 IU in the area of injection; jad owadów błonkoskrzydłych; konieczne jest posiadanie zestawu przeciwwstrząsowego w gabinecie;

b) podanie kwasu acetylosalicylowego w dawce $600 \mathrm{mg}$;

c) podanie 400 IU hialuronidazy w kilku wkłuciach co 3-4 cm w niedokrwioną okolicę; rekomenduje się podanie hialuronidazy za pomocą igły lub kaniuli o wielkości 25G;

d) zastosowanie kompresów rozgrzewających;

e) kontrola po 1 godzinie; w przypadku widocznego zbielenia skóry i/lub bólu powtórzyć punkt c;

f) kontrola po 6 godzinach; w przypadku widocznego zbielenia skóry i/lub bólu powtórzyć punkt c;

g) kontrola w dniu następnym; w przypadku widocznego zbielenia skóry i/lub bólu powtarzać punkt c do całkowitego zniwelowania zbielenia i/lub bólu [22, 34, 38].

Nie rekomenduje się stosowania nitrogliceryny ze względu na jej zdolność obkurczania naczyń w dłuższym odstępie czasu $[53,54]$.

7. Całkowite upośledzenie drożności naczynia:

a) w ostrych przypadkach, ze względu na możliwe większe powikłania spowodowane opóźnieniem wdrożenia leczenia, dopuszcza się odstąpienie od wykonywania testu śródskórnego z hialuronidazą; należy zachować szczególną ostrożność u osób deklarujących reakcję uczuleniową na jad owadów błonkoskrzydłych; konieczne jest posiadanie zestawu przeciwwstrząsowego w gabinecie;

b) podanie kwasu acetylosalicylowego w dawce $600 \mathrm{mg}$;

c) podanie 1000-1500 IU hialuronidazy lub więcej w kilku wkłuciach co 3-4 cm w niedokrwioną okolicę; rekomenduje się podanie hialuronidazy za pomocą igły lub kaniuli o wielkości 25G;

d) zastosowanie kompresów rozgrzewających;

e) kontrola po 1 godzinie; w przypadku widocznego zbielenia skóry i/lub bólu powtórzyć punkt c;

f) kontrola po 6 godzinach; w przypadku widocznego zbielenia skóry i/lub bólu powtórzyć punkt c;

g) kontrola w dniu następnym; w przypadku widocznego zbielenia skóry i/lub bólu powtarzać punkt c do całkowitego zniwelowania zbielenia i/lub bólu;

h) podawanie pentoksyfiliny 2 razy dziennie po $400 \mathrm{mg}$ przez minimum 2 tygodnie [29, 34, 38].

8. Utrata widzenia.

W przypadku utraty widzenia spowodowanej zabiegiem z użyciem HA należy pamiętać o jak najszybszym przekazaniu pacjenta na ostry dyżur okulistyczny. Obowiązuje zasada złotych 90 minut liczonych od czasu wykonania zabiegu. Należy wezwać karetkę pogotowia ratunkowego.

W oczekiwaniu na przyjazd karetki powinno się wykonać następujące działania:

a) podanie 1000-1500 IU hialuronidazy jednorazowo w miejsce iniekcji; 


\begin{tabular}{|c|c|c|}
\hline Partial & Total & Vision disorder \\
\hline & & Golden 90 minutes! \\
\hline $\begin{array}{l}\text { Test with the use } \\
\text { hyaluronidase }\end{array}$ & & Call an ambulance \\
\hline $\begin{array}{l}\text { Administer hyaluronidase } \\
\text { dose of } 400 \mathrm{IU} \text { in several } \\
\text { punctures every } 3-4 \mathrm{~cm} \\
\text { into the ischemic area }\end{array}$ & $\begin{array}{l}\text { Administer hyaluronidase } \\
\text { dose of I000- } 1500 \mathrm{IU} \\
\text { in several injections up } \\
\text { to } 3-4 \mathrm{~cm} \text { into the ischemic area }\end{array}$ & $\begin{array}{l}\text { Administer a single hyaluronidase } \\
\text { dose of I000-I500 IU } \\
\text { in the injection area }\end{array}$ \\
\hline \multicolumn{3}{|c|}{ Administer 600 mg of acetylsalicylic acid } \\
\hline \multicolumn{2}{|c|}{ Use of hot compresse } & $\begin{array}{l}\text { Retrobulbar administration of I } 500 \mathrm{IU} \\
\text { of hyaluronidase* } \\
\text { *Only for doctors who can carry out this procedure }\end{array}$ \\
\hline \multicolumn{2}{|c|}{$\begin{array}{l}\text { Control appointment on the following day, in the } \\
\text { case of visible concussion and/or pain, repeat the } \\
\text { pulses of hyaluronidase }\end{array}$} & $\begin{array}{l}\text { Administer eye drops } 0.5 \% \text { Timolol, } \\
2-3 \text { drops to the blind eye }\end{array}$ \\
\hline \multirow{3}{*}{\multicolumn{2}{|c|}{$\begin{array}{c}\text { Administer penthoxyphilin prolongatum } \\
\text { in a dose of } 2 \times 400 \mathrm{mg} \\
\text { for at least } 2 \text { weeks }\end{array}$}} & Induce hypercapnia \\
\hline & & Perform the eyeball massage \\
\hline & & $\begin{array}{c}\text { Hand the patient over to the ambulance team, } \\
\text { equip the patient with hyaluronidase and provide } \\
\text { information on the procedure - the procedure } \\
\text { of retrobulbar administration of hyaluronidase to } \\
\text { be performed in the ophthalmological emergency } \\
\text { department }\end{array}$ \\
\hline
\end{tabular}

Figure 4. The algorithm of procedures related to vascular complications after HA administration

b) administration of acetylsalicylic acid at a dose of $600 \mathrm{mg}$;

c) administration of 2-3 drops of $0.5 \%$ timolol solution to the blind eye;

d) inducing hypercapnia in the patient (e.g. by breathing into a bag);

e) performing a firm eyeball massage;

f) retrobulbar administration of 1500 IU of hyaluronidase - only for ophthalmologists or physicians experienced in the scope of this procedure [6, 35-37];

g) handing the patient over to the ambulance team, notifying them about the need to carry out the procedure of retrobulbar hyaluronidase administration in the ophthalmological emergency department and equipping the patient with a hyaluronidase ampoule.

\section{CONCLUSIONS}

Treatments with the use of HA are relatively safe for the patient, provided that they are performed by a qualified physician and appropriate procedures b) zastosowanie kwasu acetylosalicylowego w dawce $600 \mathrm{mg}$;

c) podanie $2-3$ kropli $0,5 \%$ roztworu tymololu do niewidzącego oka;

d) wywołanie hiperkapnii u pacjenta (np. poprzez oddychanie do torby);

e) wykonanie zdecydowanego masażu gałki ocznej;

f) podanie 1500 IU hialuronidazy zagałkowo - tylko w przypadku lekarzy okulistów lub lekarzy mających doświadczenie $\mathrm{w}$ wykonywaniu takiej procedury [6, 35-37];

g) przekazanie pacjenta zespołowi karetki pogotowia ratunkowego, poinformowanie o potrzebie wykonania procedury zagałkowego podania hialuronidazy na ostrym dyżurze okulistycznym oraz wyposażenie pacjenta w ampułkę hialuronidazy.

\section{PODSUMOWANIE}

Zabiegi z użyciem HA są dla pacjenta stosunkowo bezpieczne pod warunkiem wykonywania ich przez wykwalifikowanego lekarza i przy zachowaniu odpo- 


\begin{tabular}{|c|c|c|}
\hline Częściowe & Całkowite & Zaburzenie widzenia \\
\hline & & Złote 90 minut! \\
\hline Test z użyciem hialuronidazy & & \multirow{2}{*}{$\begin{array}{l}\text { Wezwać karetkę } \\
\text { pogotowia ratunkowego }\end{array}$} \\
\hline & & \\
\hline $\begin{array}{c}\text { Podać hialuronidazę w dawce } \\
400 \text { IU w kilku wkłuciach } \\
\text { co 3-4 cm } \\
\text { w niedokrwioną okolicę }\end{array}$ & $\begin{array}{l}\text { Podać hialuronidazę w dawce } \\
\text { I000- I } 500 \text { IU w kilku wkłuciach } \\
\text { do 3-4 cm } \\
\text { w niedokrwioną okolicę }\end{array}$ & $\begin{array}{c}\text { Podać hialuronidazę w dawce } \\
\text { I000-I } 500 \text { IU jednorazowo } \\
\text { w miejsce iniekcji }\end{array}$ \\
\hline \multicolumn{3}{|c|}{ Podać kwas acetylosalicylowy w dawce 600 mg } \\
\hline \multirow{2}{*}{\multicolumn{2}{|c|}{ Zastosować kompresy rozgrzewające }} & \multirow{2}{*}{$\begin{array}{c}\text { Podać I } 500 \text { IU hialuronidazy zagałkowo* } \\
\text { *Tylko w przypadku lekarzy potrafiących wykonać } \\
\text { taką procedurę }\end{array}$} \\
\hline & & \\
\hline \multicolumn{2}{|c|}{$\begin{array}{l}\text { Kontrola następnego dnia, w przypadku widocznego } \\
\text { zbielenia i/lub bólu powtórzyć puls z hialuronidazy }\end{array}$} & $\begin{array}{l}\text { Podać krople oczne 0,5\% Tymolol, } \\
\text { 2-3 krople do niewidzącego oka }\end{array}$ \\
\hline \multirow{3}{*}{\multicolumn{2}{|c|}{$\begin{array}{l}\text { Podawać pentoksyfilinę prolongatum } \\
\text { w dawce } 2 \times 400 \mathrm{mg} \\
\text { przez min. } 2 \text { tygodnie }\end{array}$}} & Wywołać hiperkapnię \\
\hline & & Wykonać masaż gałki ocznej \\
\hline & & $\begin{array}{l}\text { Przekazać pacjenta zespołowi karetki pogotowia } \\
\text { ratunkowego, wyposażyć pacjenta w hialuronidazę } \\
\text { i przekazać informacje o postępowaniu - } \\
\text { procedura zagałkowego podania hialuronidazy } \\
\text { do wykonania na SOR okulistycznym }\end{array}$ \\
\hline
\end{tabular}

Rycina 4. Algorytm postępowania w przypadku powikłań naczyniowych po zastosowaniu HA

are applied, as well as tested preparations are used. The total percentage of complications does not exceed $1 \%$. Complications after HA treatments include vascular and non-vascular complications. Vascular complications are particularly dangerous due to the occurrence of an impaired vessel patency, which can lead to skin necrosis or even loss of vision. One of the main therapeutic actions in most of the complications presented in the publications is administration of appropriate amount of hyaluronidase preparation to the patient. It is crucial for doctors and their patients to know the treatment patterns and to implement appropriate treatment in case of specific complications as soon as possible (fig. 4).

\section{CONFLICT OF INTEREST}

The article was prepared by the Aesthetic Dermatology Section of the Polish Dermatological Society owing to the educational grant of Galderma Polska Sp. z o.o. wiednich procedur, a także stosowania przebadanych preparatów. Ogólny odsetek powikłań takich zabiegów nie przekracza $1 \%$. Powikłania po zabiegach z użyciem HA mogą mieć charakter naczyniowy i nienaczyniowy. Powikłania naczyniowe są szczególnie niebezpieczne ze względu na wystąpienie upośledzenia drożności naczynia, które może prowadzić do martwicy skóry lub nawet utraty widzenia. Jednym z podstawowych działań leczniczych $\mathrm{w}$ większości przedstawionych $\mathrm{w}$ publikacji powikłań jest podanie pacjentowi hialuronidazy w odpowiedniej ilości. Kluczowa dla lekarzy oraz ich pacjentów jest znajomość schematów leczenia oraz jak najszybsze wdrożenie odpowiedniej terapii w przypadku wystąpienia poszczególnych powikłań (ryc. 4).

\section{KONFLIKT INTERESÓW}

Artykuł został zrealizowany przez Sekcję Dermatologii Estetycznej Polskiego Towarzystwa Dermatologicznego dzięki wsparciu grantu edukacyjnego firmy Galderma Polska Sp. z o.o. 


\section{References}

Piśmiennictwo

1. American Society of Plastic Surgeons: 2017 Plastic Surgery Statistics Report. Available at: https://www.plasticsurgery.org/ documents/News/Statistics/2017/cosmetic-procedure-trends- 2017.pdf. Accessed January 19, 2019

2. American Society of Plastic Surgeons: 2008 Report of the 2007 Statistics. Available at: https://www.plasticsurgery.org/ documents/News/Statistics/2007/plastic-surgery-statistics-full- report-2007.pdf. Accessed January 19, 2019.

3. ISAPS International Survey on Aesthetic/Cosmetic Procedures: Report available at: http://www.isaps.org/wp" www. isaps.org/wp content/uploads/2018/10/ISAPS_2017_International_Study_Cosmetic_Procedures.

4. Beauvais D., Ferneini EM.: An overview of vascular adverse events associated with facial soft tissue fillers: recognition, prevention, and treatment. J Oral Maxillofac Surg 2019 https://doi.org/10.1016/j.joms.2019.08.003

5. Cavallini M., Gazzola R., Metalla M., Vaienti L.: The role of hyaluronidase in the treatment of complications from hyaluronic acid dermal fillers. Aesthet Surg J 2013, 33, 1167-1174.

6. Beleznay K., Carruthers J.D., Humphrey S., Jones D.: Avoiding and treating blindness from fillers: a review of the world literature. Dermatol Surg 2015, 41, 1097-1117.

7. Ozturk C.N., Li Y., Tung R., Parker L., Piliang M.P., Zins J.E.: Complications following injection of soft-tissue fillers. Aesthet Surg J 2013, 33, 862-877.

8. Doerfler L., Hanke C.W.: Arterial occlusion and necrosis following hyaluronic acid injection and a review of the literature. J Drugs Dermatol 2019, 18, 587-591.

9. Glogau R.G., Knott H.M.: Fillers: evolution, regression, and the future. In: Soft Tissue Augmentation. $3^{\text {rd }}$ edn. J. Carruthers, A. Carruthers (eds.). Elsevier Saunders, China 2013, 3-9.

10. Barańska-Rybak W.: Powikłania po korekcji zmarszczek kwasem hialuronowym - postępowanie i leczenie. Dermatol Dypl 2015, 5, 1-7.

11. Bass L.S.: Injectable filler techniques for facial rejuvenation, volumization, and augmentation. Facial Plast Surg Clin North Am 2015, 23, 479-488

12. Beleznay K., Carruthers J.D., Humphrey S., Jones D.: Update on avoiding and treating blindness from fillers: a recent review of the world literature. Aesthet Surg J 2019, 39, 662-674.

13. Beauvais D., Ferneini E.M.: Complications and litigation associated with injectable facial fillers: a cross-sectional study. J Oral Maxillofac Surg 2020, 78, 133-140.

14. Lemperle G., Rullan P.P., Gauthier-Hazan N.: Avoiding and treating dermal filler complications. Plast Reconstr Surg 2006, 118 (3 Suppl), 92-107.

15. Hwan C.J., Perry J.D.: Filler complications. Ad Cosmetic Surg 2018, 1, 143-150.

16. Graivier M.H., Bass L.M., Lorenc P., Fitzgerald R., Goldberg D.J., Lemperle G.: Differentiating nonpermanent injectable fillers: prevention and treatment of filler complications. Aesthet Surg J 2018, 38, 29-40.

17. Hwang C.J.: Periorbital injectables: understanding and avoiding complications. J Cutan Aesthet Surg 2016, 9, 73-79.

18. Urdiales-Galvez F., Delgado N.E., Figueiredo V., Lajo-Plaza J.V ., Mira M., Moreno A., et al.: Treatment of soft tissue filler complications: expert consensus recommendations. Aesth Plast Surg 2018, 42, 498-510.

19. Sadeghpour M., Quatrano N.A., Bonati L.M., Arndt K.A., Dover J.S., Kaminer M.S.: Delayed-onset nodules to differentially crosslinked hyaluronic acids: comparative incidence and risk assessment. Dermatol Surg 2019, 45, 1085-1094.

20. Funt D., Pavicic T.: Dermal fillers in aesthetics: an overview of adverse events and treatment approaches. Clin Cosmet Investig Dermatol 2013, 6, 295-316.

21. King M.: Management of Tyndall effect. J Clin Aesthet Dermatol 2016, 9, 6-8.

22. Philipp-Dormston W.G., Bergfeld D., Sommer B.M., Sattler G., Cotofana S., Snozzi P., et al.: Consensus statement on prevention and management of adverse effects following rejuvenation procedures with hyaluronic acid-based fillers. J Eur Acad Dermatol Venereol 2017, 31, 1088-1095.

23. Maciejewska M., Bauer M., Dawgul M.: Nowoczesne metody zwalczania biofilmu bakteryjnego. Post Mikrobiol 2016, 55, 3-11.

24. Saththianathan M., Johani K., Taylor A., Hu H., Vickery K., Callan P., et al.: The role of bacterial biofilm in adverse soft-tissue filler reactions: a combined laboratory and clinical study. Plast Reconstr Surg 2017, 139, 613-621.

25. DeLorenzi C.: Complications of injectable fillers, part I. Aesthet Surg J 2013, 33, 561-575.

26. Marusza W., Olszanski R., Sierdzinski J., Ostrowski T., Szyller K., Mlynarczyk G., et al.: Treatment of late bacterial infections resulting from soft-tissue filler injections. Infect Drug Resist 2019, 12, 469-480.

27. Chang S.H., Yousefi S., Qin J., Tarbet K., Dziennis S., Wang R., et al.: External compression versus intravascular injection: a mechanistic animal model of filler-induced tissue ischemia. Ophthal Plast Reconstr Surg 2016, 32, 261-266.

28. DeLorenzi C.: New high dose pulsed hyaluronidase protocol for hyaluronic acid filler vascular adverse events. Aesth Surg J 2017, 37, 814-825.

29. Walker L., King M.: This month's guideline: visual loss secondary to cosmetic filler injection. J Clin Aesthet Dermatol 2018, $11,53-55$.

30. Woodward J., Khan T., Martin J.: Facial filler complications. Facial Plast Surg Clin N Am 2015, 23, 447-458.

31. Ferneini E.M., Ferneini A.M.: An overview of vascular adverse events associated with facial soft tissue fillers: recognition, prevention, and treatment. J Oral Maxillofac Surg 2016, 74, 1630-1636.

32. DeLorenzi C.: Complications of injectable fillers, part 2: vascular complications. Aesthet Surg J 2014, 34, 584-600.

33. Sito G., Manzoni V., Sommariva R.: Vascular complications after facial filler injection: a literature review and metaanalysis. J Clin Aesthet Dermatol 2019, 12, 65-72.

34. Urdiales-Gálvez F., Delgado N.E., Figueiredo V., Lajo-Plaza J.V., Mira M., Moreno A., et al.: Treatment of soft tissue filler complications: expert consensus recommendations. Aesthetic Plast Surg 2018, 42, 498-510. 
35. Lazzeri D., Agostini T., Figus M., Nardi M., Pantaloni M., Lazzeri S.: Blindness following cosmetic injections of the face. Plast Reconstr Surg 2012, 129, 995-1012.

36. Beleznay K., Carruthers J.D.A., Humphrey S., Jones D.: Avoiding and treating blindness from fillers: a review of the world literature. Dermatol Surg 2015, 41, 1097-1117.

37. Kim Y.J., Choi K.S.: Bilateral blindness after filler injection. Plast Reconstr Surg 2013, 131, $298-299$.

38. Hirsch R.J., Brody H.J., Carruthers J.D.A.: Hyaluronidase in the office: a necessity for every dermasurgeon that injects hyaluronic acid. J Cosmet Laser Ther 2007, 9, 182-185.

39. Buhren B.A., Schrumpf H., Hoff N.P., Bölke E., Hilton S., Gerber P.A.: Hyaluronidase: from clinical applications to molecular and cellular mechanisms. Eur J Med Res 2016, 21, 5.

40. World Health Organization: WHO guidelines on transmissible spongiform encephalopathies in relation to biologic and pharmaceutical products, 2003. http://www.int/bloodproducts/pub.

41. Thorpe J.N.: Procaine with hyaluronidase as local anesthetic. Lancet 1951, 1, 210-211.

42. Clark L.E., Mellette J.R. Jr.: The use of hyaluronidase as an adjunct to surgical procedures. J Dermatol Surg Oncol 1994, 20, 842-844.

43. Wohlrab J., Finke R., Franke W.G., Wohlrab A.: Efficacy study of hyaluronidase as a diffusion promoter for lidocaine in infiltration analgesia of skin. Plast Reconstr Surg 2012, 129, 771-772.

44. Bailey S.H., Fagien S., Rohrich R.J.: Changing role of hyaluronidase in plastic surgery. Plast Reconstr Surg 2014, 133, 127-132.

45. Lambros V.: The use of hyaluronidase to reverse the effects of hyaluronic acid filler. Plast Reconstr Surg 2004, 114, 277.

46. Rzany B., Becker-Wegerich P., Bachmann F., Erdmann R., Wollina U.: Hyaluronidase in the correction of hyaluronic acidbased fillers: a review and recommendation for use. J Cosm Dermatol 2009, 8, 317-323.

47. Casabona G., Barreto Marchese P., Montes J.R., Hornfeldt C.S.: Durability, behavior and tolerability of 5 hyaluronidase products. Dermatol Surg 2018, 4, 42-50.

48. Buhren B.A., Schrumpf H., Bölke E., Kammers K., Gerber P.A.: Standardized in vitro analysis of the degradability of hyaluronic acid fillers by hyaluronidase. Eur J Med Res 2018, 23, 37.

49. Park T.H., Seo S.W., Kim J.K., Chang C.H.: Clinical experience with hyaluronic acid-filler complications. J Plast Reconstr Aesthetic Surg 2011, 64, 892-896.

50. Wu L., Liu X., Jian X., Wu X., Xu N., Dou X., et al.: Delayed allergic hypersensitivity to hyaluronidase during the treatment of granulomatous hyaluronic acid reactions. J Cosmetic Dermatol 2017, 6, 991-995.

51. Kirby B., Butt A., Morrison A.M., Beck M.H.: Type I allergic reaction to hyaluronidase during ophthalmic surgery. Contact Dermatitis 2001, 44, 44-45.

52. Cavallini M., Gazzola R., Metalla M., Vaienti L.: The role of hyaluronidase in the treatment of complications from hyaluronic acid dermal fillers. Aesthet Surg J 2013, 33, 1167-1174.

53. Hwang C.J., Morgan P.V., Pimentel A., Sayre J.W., Goldberg R.A., Duckwiler G.: Rethinking the role of nitroglycerin ointment in ischemic vascular filler complications: an animal model with ICG imaging. Ophthal Plast Reconstr Surg 2016, 32, 118-122.

54. Carley S.K., Kraus C.N., Cohen J.L.: Nitroglycerin, or not, when treating impending filler necrosis. Dermatol Surg 2020, 46 , 31-40.

Received: 22.01.2020

Accepted: 25.02 .2020

Otrzymano: $22.01 .2020 \mathrm{r}$

Zaakceptowano: $25.02 .2020 \mathrm{r}$.

How to cite this article

Zegarska B., Ambroziak M., Ornatowska M., Barańska-Rybak W.: Management of complications associated with the use of hyaluronic acid fillers. Recommendations of the Aesthetic Dermatology Section of the Polish Dermatological Society.

Dermatol Rev/Przegl Dermatol 2020, 107, 15-31. DOI: https://doi.org/10.5114/dr.2020.93968. 